\title{
Akal Budi Melayu dalam Pantun dan Sajak (Malay Version)
}

Iqbal U*

History Programme, Faculty of Social Sciences and Humanities, National University of Malaysia, Malaysia

*Corresponding author: Iqbal U, History Programme, Faculty of Social Sciences and Humanities, National University of Malaysia, UKM 43650, Bangi Selangor, Malaysia, Tel: 60389215555; E-mail: uqbah@siswa.ukm.edu.my

Received date: November 26, 2015; Accepted date: December 15, 2015; Published date: December 21, 2015

Copyright: () 2015 Iqbal U. This is an open-access article distributed under the terms of the Creative Commons Attribution License, which permits unrestricted use, distribution, and reproduction in any medium, provided the original author and source are credited.

\section{Commentary}

Literature is at the heart of civilization must be able to contribute towards building a great culture. Features literature must demonstrate a clear vision and true, maintain artistic refinement, blending natural view and cultivated high art, analytical exploration of every aspect of humanity, can appreciate the emotional upheaval of the soul and the characters are highlighted and are skilled in the use of language style works its literature. What is more important is to make use of Malay literature in particular through the poem and the rhyme as a handle and practice in the life and activities of the Malay community and other races to strengthen the unity and racial harmony. As essentially literary materials in Arts components (Komsas) may play this role. Therefore, to study Malay common sense is an exciting and fun business. The formation of a civilized races starts from common sense.

To explore the Malay common sense must be through an understanding of the poem and the rhyme. Through the spoken pronunciation of the poem orally and then written the Malay common sense reflected through all the traditional life activities. Thus, the emission of the Malay common sense also is continuity in the new poetry namely rhymes. Poetry in Komsas text as a tool for teaching and learning towards shaping a humane people. Its content has a philosophy and wisdom through the various elements of effective teaching form of humanity if learned and practiced in life, particularly at youth level.

Chapter 1 explains that Malay literature has become a mandatory component in the teaching and learning of the Malay Language in secondary schools such as the arts, science, engineering, religion and vocational education in Malaysia. Students are required to read and study the books of the Malay literature. The use of literature in the Malay Language currently implemented through Komsas. Komsas text in English consists of poetry, short stories, dramas and novels.

Chapter 2 describes the common sense concept namely the definition of the brain and discretion; based on al-Quran and Islamic scholars view; common sense from by French scholars view; common sense from Eastern and Western scholars view and common sense as a philosophy of the Malays life. Education about common sense should be conducted from time to time and the purification was performed at the school level through education.

Chapter 3 describes about Komsas. Komsas text in the Malay Language, insert the Malay literary text consists of poems, short stories, dramas and novels taught in the teaching and learning of the Malay Language in secondary schools in Malaysia. The students from form one to form five compulsory to study this text and will also be given a question about it in the Lower Secondary Assessment and Malaysian Certificate of Education exams. Thus, through the Komsas text is expected to develop students' potential through quality education system and world-class to expand individual's potential and fulfill the aspirations of the country. Efforts to make a balanced and harmonious person from aspects of intellectually, spiritually, emotionally and physically by faith and devotion to God will be accomplished through education literature, particularly from the Komsas text.

To view the Malay common sense through poetry, chapter 4 analyzes the quatrains contained in the Komsas text, starting from form one to form five. History proves that poetry has a long string entered public life. Since young until adult poetry or songs filled the emptiness of the soul and a comfort to the people. Poetry also could change someone's life towards a better and meaning life. For example, in Malay traditional medicine poetic form of the mantra often used to treat the disease.

In chapter 5, the Komsas text selection poems from form one to form five consists of poems by the new and old poet encompasses a diversity of themes and issues. The text of the form one poem comprising six poems, form two, six poems, form three, six poems, form four, six poems and form five, six poems which amounted to thirty poems. The poem text selection is to see the thinking mind towards education which coincides with the field of aesthetic learning outcomes as outlined in the syllabus of the Malay Language KBSM.

After analyzing the poem and the rhyme by using the concept of Malay common sense contained in both the genre, this writing found a lot of common sense in the poem and the rhyme of Komsas text from form one to form five.

Chapter 6 will focus on the thoughts, words and actions contained in the poem and the rhyme. Chapter 6 will also touch on the elements that have a significant relationship between common sense and education through literature containing positive values and values of morality to establish a better human being. The concept of common sense is based on the National Education Philosophy obviously trying to improve thinking ability in students with language skills and produce students who creatively and critically, to increase the strength of spiritual, intellectual, emotional and physical. Students will also be able to manage their own emotions that become a barrier to the threat of negative symptoms which are also a threat to life in the present and the future. Hence, education and literature studies are very important in building an intelligence community in Malaysia. Writing this is a preliminary analysis that needs to be extended in the future to determine the effectiveness of a literary work in education. Thus, through writing and other studies may be extended by using students as the respondent, because those who receive Komsas education directly will become leaders in the future. 